\title{
Resisting the Giants: Small Retail Entrepreneurs Against Mega-Retailers-An Empirical Study
}

\author{
B. Cotton, School of Commerce and Administration, Laurentian \\ University, Sudbury, Ontario
}

\section{J.-Ch. Cachon, School of Commerce and Administration, Laurentian University, Sudbury, Ontario}

ABSTRACT. Mega-retailers are widely criticized as causing devastation among smaller retailers, particularly in mid-sized markets in the United States. Others argue that small retailers can survive "in the shadow of the retail giants," by offering levels of customer service that the mega-retailers can't provide due to their very size. This paper reports the findings of an empirical study of the perceived impact of the recent opening of box-retailers, such as Costco and Home Depot on locally owned/operated small retailers in the northeastern Ontario city of Greater Sudbury, Canada from 1999 to 2003. The sample included 78 smaller store owners, on average in operation for the last 21 years.

Aggregate results confirmed the hypotheses that small retailers suffered lower sales and clientele since the arrival of mega-retailers, and could clearly identify their and mega-retailers' respective competitive advantages and disadvantages as compared to each other. Respondents had a significant perception of having an advantage over their mega-competitors in the areas of Store Cleanliness, Value for the Customer, Products' Quality, and Store Layout. While a number of respondents suffered lower sales, about one-third of them (the Resisting Retailers) had average sales growth of over $21 \%$. Differentiation and Niche Marketing were the main aspects of a successful competing strategy adopted by resisting retailers against mega-retailers. Some of the strategic moves adopted by resisting retailers amounted to a "Vacuum Strategy," which includes the refusal to carry brands available at mega-stores, and the refusal to service such brands or to have anything to do with megaretailers, refusing any alliance with them and making it known to customers.

SOMMAIRE. Les méga-détaillants se font souvent critiquer pour semer la ruine chez les petits détaillants, surtout dans les marchés moyens des Etats-Unis. Certains, par contre, maintiennent que les petits détaillants peuvent survivre «à l'ombre des géants du détail » en offrant un service à la clientele qui n'est pas disponible aux méga-détaillants. Le présent article présente les conclusions d'une étude empirique sur l'impact ressenti à l'occasion de l'ouverture récente de grandes surfaces telles que Costco et Home Depot par les petits détaillants de Greater Sudbury, au nord-ouest de l'Ontario (Canada), entre 1999 et 2003. L'échantillon comprenait 78 propriétaires de petits magasins, en service pour la plupart depuis 2 I ans.

Les résultats d'ensemble confirment l'hypothèse que les petits détaillants confrontent une baisse des ventes et de la clientèle depuis l'arrivée des méga-détaillants, et identifient clairement, en les comparant, les avantages et désavantages concurrentiels des deux groupes. Les répondants avaient la forte impression de posséder un avantage sur leurs méga-concurrents dans ces domaines : propreté du magasin, qualité du service, qualité du produit, et aménagement du magasin. Tandis qu'un certain nombre de répondants ont subi une baisse des ventes, environ un tiers d'entre eux (les resistants) ont vu leurs ventes monter en moyenne de $21 \%$. La différenciation et la mercatique de créneau représentent les principaux aspects d'une stratégie concurtentielle fructueuse adoptée par les résistants contre les méga-détaillants. Certaines des actions adoptées équivalaient à une «stratégie par le vide» consistant à refuser de vendre les marques disponibles dans les grandes surfaces ou de s'occuper de leur service après vente, à éviter tout rapport avec leurs concurrents, et à faire connaître leur démarche à leur clientèle. 


\section{Introduction}

This paper reports the findings of an empirical study of the perceived impact of the opening of mega-, or box-, retailers on locally owned/operated small- to medium-sized retailers in NorthEastern Ontario, Canada. The study focused on the City of Greater Sudbury (CGS). A Census Metropolitan Area (CMA), the CGS is located in northern Ontario, a region known for its spectacular lakes, forests, and fauna as well as for its frigid winter weather: it is the region used by most North American and Japanese motor vehicle manufacturers as a cold-weather testing ground. The CGS has also been a Canadian market test city for several decades.

With a market of approximately 550,000 people, relatively isolated from large urban centers such as the Greater Toronto Area (GTA), northern Ontario and the adjacent northwestern Quebec area, the region represents an ideal life-size laboratory enabling the observation of the emerging battle between established local small retailers and the large mega-retailers such as Costco and Home Depot. The former opened in the CGS in 1999 and was quickly followed by Home Depot in an adjacent location. Subsequent openings of a number of similarly large stores continue in that location, resulting in the emergence of a significant northeastern Ontario power center involving around thirty stores. As the results below will show, some local smaller entrepreneurs have decided to fight, and a good number of them are resisting the giants with varying degrees of success.

The researchers also tried to identify what competitive advantages smaller retailers reported to be attempting to develop or maintain, as they were confronted with the entry of mega-retailers into their immediate vicinity and within the regional market. The questions related to the impact of mega-retailers on specific categories of retailers, and the issues related to the respective location of mega- and small retailers were also examined, as well as the positive, neutral, or negative financial impact of mega-retailers upon small retailers. The characteristics of those retailers who were successfully competing or resisting against mega-retailers as well as those of the unsuccessful ones so far were examined.

\section{Definition}

A number of terms are attached to retail "super" store operations, including "hypermarkets" in Europe (Gonzalez-Benito, 2001), and in North America "box retailers," "discount retailers" and "mega-retailers." These terms generally apply to stores which are 2,500 sq. meters in surface (or $26,900 \mathrm{sq}$. ft.), but many new stores are 7,500 sq. meters and more $(80,700$ sq. $\mathrm{ft}$.). In this study the term "mega-retailer" is used, since this appears to be the more common generic title and includes four types of large retail operations: discount stores such as Wal-Mart, category killers such as Home Depot, warehouse clubs such as Costco, and outlet stores such as The Shoe Company.

\section{Literature Review}

Although there are numerous anecdotal press reports regarding the effects of mega-retailers, Wal-Mart in particular, empirical research reports are limited. Noteworthy US studies, including Beaumont (1994), Stone (1995 and 1997), Stone and Artz (1999), Shils and Taylor (1997), have concluded that the opening of mega-retailers in a community has the potential to impact on existing smaller merchants in two ways. Firstly, there will be an effect on the retail sector in terms of changes to sales levels: increasing in outlets in the immediate area carrying different product categories to the mega-retail outlets, as a result of increased traffic. However, decline occurs in the overall market area in outlets carrying similar categories (Stone and Artz, 1995). Secondly, changes in the way the merchants 
conduct their business in terms of competitive strategies: reduction in number of employees, due either to lower sales levels or to increased efficiencies and changes in marketing practices-pricing, product mix and store positioning, location of outlet and recognition of customer service as being central to survival. Others also point out that retail success is entirely dependent on a local economy's ability to generate purchasing power for the customers, while retailers drain wealth away from an area (Fruth, 2000).

Shils and Taylor's (1999) comprehensive study identifies both social and economic effects, the social effects being the physical and social decline of neighborhoods as preexisting retailers fail to survive, noting (in areas visited) "profound changes in joblessness and socialization." The more serious economic effects include, firstly, retail closures as traditional retailers fail to compete, with the consequent loss of jobs including the employment of the owners themselves. Secondly, reduced numbers of employees was noted; a result of Shil and Taylor's "drain away" effect caused by the presence of mega-retailers shifting activities from various geographic traditional retail centers or clusters.

In seeking community approval to locate stores, mega-retailers have promised increased job numbers. In several cases it is reported that the number of jobs have not materialized to the extent promised, a situation exacerbated by the fact that, according to the Shils and Taylor study, "in exchange for 1 new part-time job in a mega-discount store, about 1.5 full-time jobs are eliminated in smaller stores." Further, most jobs in the megaretail stores are "minimum wage" with little opportunity for improvement or promotion. Most are non-union with all the ramifications implicit in such situations (i.e. absence of provision of benefits to large numbers of employees). In some situations, they report, the mega-retailers have closed down operations after several years. Having forced the closure of much of the local retail trade, the closures leave a retail vacuum and an increased unemployment problem (Dalal, Al-Khatib, DaCosta and Decker, 1994).

Shils and Taylor pointed to the erosion of "free retail market" choice for consumers both in terms of choice of retailer, shopping location and brand and other choice issues. Citing a 1996 statement of Wal-Mart's CEO, David D. Glass, at their annual stockholders meeting of that year, "We are going to dominate North America!," they point to the "decimation of communities" "main street" retailers, unable to compete.

Conversely, Archer and Taylor (1994) argue that small retailers can survive "in the shadow of the retail giants," the key being levels of customer service that the mega-retailers can't provide, their very size limiting their abilities in this area. More specifically, Berry $(1999,2001)$ contends that by using five well-documented retailing best practices, the "Five Pillars of Retailing," survival and success can be achieved. Berry's "Five Pillars" of retailing or best retail practices, components of his "retail model," are:

1. Solve Customers' Problems;

2. Treat Customers with Respect;

3. Connect with Customers' Emotions;

4. Set the Fairest (not lowest) Price;

5. Save Customers' Time.

Berry argues that all five of these practices must be implemented in order for the concept to be effective. For the purpose of this study, the authors have developed the five scales described below in the "Methodology" section.

Studying the impact of mega-retail mainly in the Toronto area in Canada, researchers at the Ryerson University Center for the Study of Retail Activity (Doucet and Jones 1999) found that employment and sales had increased among mega-retailers, and decreased 
among their smaller competitors located in storefront retail strips. They also found that stores located closer to mega-stores suffered the most.

\section{Setting of the Study and Mega-retail Background of the Region}

\section{Expansion of Mega-retailers into Ontario}

While mega-retailing can be traced back to the creation of the first department store by Aristide Boucicaut in Paris in 1852 (Chirouze, 2003), and to the opening of a first Woolworth store in 1879 in Lancaster, Pennsylvania (Perry, 2001), the arrival of megaretailing in Canada generally, and Ontario in particular, has been the result of the expansion of US mega-retailers into the country since the late 1980's. Insofar as Ontario is concerned, until 1999 expansion was confined largely to the more populous southern part of the province. The greatest expansion of mega-retail outlets is occurring in the Greater Toronto Area (GTA). Jones and Doucet (1998) record 93 outlets of this form (a total of 4.5 million square feet) in the GTA area by 1990 increasing to 268 stores ( 11.1 million sq. $\mathrm{ft}$.) by 1998 . Expansion has continued with 2002 data showing 614 outlets ( 29 million sq. ft.) (Hernandez, Biasotto and Jones, 2003; Hernandez, Jones, and Maze, 2003; Simmons, 2003).

\section{Setting}

The setting of the study is the City of Greater Sudbury, occupying a key location on the Trans-Canada (East-West) main highway and a hub for access to much of northeastern and northwestern Ontario from either Toronto or Ottawa. Located 240 miles north of the GTA, the city has a population of over 160,000 people.

\section{Mega-retail Background in the CGS}

With the exception of Business Depot-Staples, who opened a modest-sized store in 1993 and Wal-Mart, who acquired a small Woolco store in 1994, mega-retailers' real expansion into northern retail market areas beyond Barrie, a sleeper town some 60 miles north of the GTA, occurred in 1999 with the opening of the approximately $140,000 \mathrm{sq}$. $\mathrm{ft}$. Price/Costco Warehouse Membership Club (WMC) store in the City of Greater Sudbury (CGS) in northern Ontario. This was quickly followed by the opening of the 150,000 -sq.-ft. Home Depot adjacent to the Costco location in Sudbury. With the subsequent opening of other mega-retailers, including Pier 1, Danier Leather, Homesense, ShoeSource, Mark's Work Wearhouse, Chapters-Starbucks, and a large Sears Home furniture and appliance outlet in the same location, a significant "power centre" was being created in the north of the city.

Winners and Wal-Mart have also opened stores in other locations, both in the northend of Sudbury, in recent years. Wal-Mart are building a 105,000 sq. $\mathrm{ft}$. plus second store in the south end of the city with capacity expansion potential for a further 35,000 sq.ft. A further $150,000 \mathrm{sq}$. $\mathrm{ft}$. of added retail space in the south end was occurring with the expansion of a retail mall through an existing but much-expanded Zellers discount department store (a Canadian-based chain, formerly a subsidiary of the US-based chain, K-Mart, purchased by the Hudson's Bay Company retail chain in 1996) targeted against Wal-Mart, being the key anchor in that expansion. It is expected that Greater Sudbury would host about 50 mega-retail stores by the end of 2005 .

\section{Mega-retailers' Market Area}

The designated market area (Malone, Given and Parsons, 1996) from which the megastores in the CGS attract customers comprises much of northeastern Ontario and parts of 
the western Abitibi-Temiscamingue region located in the west part of the province of Quebec. Greater Sudbury forms the pivotal center of an area containing a total population of approximately half a million people all within 200 miles of Sudbury. The market area embraces a number of small- to medium-sized rural communities and cities, including Parry Sound to the south-east, Killarney to the south, Elliot Lake and Sault St. Marie to the west; Hearst, Kapuskasing, Rouyn-Noranda (Québec), Kirkland Lake and Timmins to the North and New Liskeard, Temagami, and North Bay to the east-northeast. More detailed discussions of the economic structure of the region have been published elsewhere (Cachon et al., 2001; Mulholland et al., 1998).

Two aspects of the issue of the impact of mega-retailers on the economy in the CGS and area are important to note. Firstly, the region is vast (about $60 \mathrm{~km}$ from East to West and $30 \mathrm{~km}$ from north to south for the Sudbury Basin) and is considered to be relatively remote from the major population centers of the Greater Toronto Area and Barrie, where the nearest mega-retail outlets are located. This aspect is discussed further in the "Methodology" section below.

Secondly, in many cases, particularly in the United States where individual rural regions are in constant competition to save local jobs, mega-retailers, have been attracted into regions by low-cost land and promises of property tax exemptions offered by local authorities in the belief that permitting such developments would increase opportunities and improve general economic conditions. This did not occur in Sudbury where the local authorities have made the companies responsible not only for property taxes, but also for infrastructure modifications including roadways, drainage and other municipal or utilityprovided services.

\section{Research Methodology}

Hypotheses

Drawing on the results of the earlier research cited in the literature review, the following hypotheses were formulated:

1. Small retailers have seen a drop in gross sales since mega-retailers came to the city;

2. Small retailers have seen less out-of-city clientele since mega-retailers came to the city;

3. Small retailers can identify clearly their competitive advantages and disadvantages as compared to mega-retailers;

4. Small retailers can clearly identify the competitive advantages and disadvantages of the mega-retailers;

5. Small retailers are involved in planning innovative competitive strategies to enable them to better compete with mega-retailers;

6. Small retailers located within five miles of the mega-retailers have seen a significantly stronger decrease in gross sales, as compared to retailers located further away;

7. Small retailers located within five miles of the mega-retailers have seen a significantly stronger decrease in profits, as compared to retailers located further away.

\section{Secondary Data Sources}

In addition to the reports noted in the literature review, secondary data included municipal retailer and product/service category data on a local basis. In addition, copies of market review and impact studies conducted on behalf of Costco and others were obtained; such studies are required by the local municipality's planning authority and provide a useful perspective. 


\section{Primary Data Sources}

Primary data were collected using a cluster sampling approach involving 180 retailers within a 20-mile radius of the center of the CGS and in the primary retail clusters described above; 78 , or $43.3 \%$ of the retailers contacted participated in the survey, a proportion similar to that obtained in earlier studies involving personal interviews with retail store owners (Cachon and Cotton, 1997). Retailers trading in product categories directly affected by the box stores were identified on the basis of the Statistics Canada 1980 Standard Industrial Classification system. They included food, liquor, and prescription drug stores, shoe, apparel and fabric stores, household furnishing, electronics, and appliance stores, automotive parts stores, general merchandise stores and other retail stores such as book and stationery stores, florist shops, lawn and garden centers, hardware, paint and wallpaper stores, sporting goods stores, musical instrument and record stores, jewelry stores, camera and photographic supply stores, toy, gift, hobby and novelty stores, opticians, art galleries, artists' supplies stores, luggage stores, pet shops, and discount retailers.

\section{Sample}

Four geographic cluster samples were used and included the four primary retail activity areas in the CGS area: the City Center, the area in the south end of the CGS known as The Four Corners, the North-end of Sudbury (New Sudbury), and the suburban areas of Nickel Center, Rayside-Balfour and Valley East, all within a 20-mile radius from the center of the city. The sample included 78 smaller store owners, on average in operation for the last 21 years, with an average business surface of $3,230 \mathrm{sq}$. ft. (as compared to 50,000 to 140,000 sq. $\mathrm{ft}$. for mega-retailers).

\section{Instrument}

A semi-structured, 22-question instrument was developed and pre-tested by the authors. It was reviewed and approved by Laurentian University's Ethics Review Board. The questionnaire included a scale comprising 18 items covering the 5 sets of retail practices proposed by Berry, based upon store image variables previously developed and used by the authors (Cachon, 1990; Marks, 1976). The questionnaire was administered during the summer and fall of 2003.

The scales used to measure the five components of Berry's model included the following variables:

1. Solve Customers' Problems:

Competence of salespeople

Availability of salespeople

Service quality to clients

2. Treat Customers with Respect

Treating customers with respect

Courteous salespeople

3. Connect with Customers' Emotions through the retail experience

Cleanliness of the store

Choice/variety of products

Suppliers/supply chain

Value/value chain (any advantages given to clients as compared to competitors)

Quality of products

4. Set the Fairest (not lowest) Price

Fair pricing

Avoiding hidden charges for customers 
5. Save Customers' Time

Store location

Short cash waiting lines

Convenient shopping hours

Easy to figure, non-confusing store layout

Easy access by road

Easy parking

Data Analysis

The data were analysed with versions 11.5 and 12 of SPSS for Windows. Descriptive as well as other statistical analyses were performed.

\section{Descriptive Statistics}

\section{Results}

The CGS small retail shops are typically family-owned businesses often involving more than one generation of entrepreneurs. In terms of location, 17 small stores were located within two miles of the mega-retailers in New Sudbury, 18 were located in the City Center area, less than three miles from the mega-stores, 22 were located in the Four Comers, approximately five miles from the mega-stores, and the remaining 21 respondents were located in suburban areas between ten and twenty miles away from the mega-stores.

On average, the 78 entrepreneurs surveyed employed 4.75 full-time employees in 2003, as compared to 4.92 in 1997 (i.e. two years before the opening of the first megastore), and 3.39 part-timers in 2003, as compared to 3.27 in 1997. Between 1999 (year of the opening of the first mega-store) and 2003, smaller-store owners reported an average decline in sales of minus $7.51 \%$ for the period, an average decline in profits of minus $2.94 \%$, and an average decline of customer traffic of $7.51 \%$ from Greater Sudbury and of $0.71 \%$ from outside the Sudbury area. These results confirm hypotheses 1 and 2 .

In terms of competition, 53 respondents $(67.9 \%)$ identified large discount retail chains as their competitors, and 25 of them named Home Depot and Costco as being these competitors. The remainder of the respondents saw themselves more in competition with other smaller retailers, or considered that a niche marketing strategy prevented them from having real competition to speak of within their perceived target market area.

\section{Unsuccessful Retailers}

37 of the 78 respondents $(47.4 \%$ ) reported that their sales volume had decreased since the arrival of the mega-stores, in a range from minus $6 \%$ to minus $50 \%$, with an average decrease of minus $21.3 \%$. As a consequence, they had to reduce their average number of full-time employees from 7 to 5.75, and their average number of part-time employees from 4.33 to 3.78 , even if their stores were, on average, slightly larger than the overall average $(3,477 \mathrm{sq}$. ft. vs. $3,230 \mathrm{sq}$. $\mathrm{ft}$.). In terms of profitability, the average decline among this group was $12.35 \%$, almost half the decline in sales, suggesting that adjustment measures had already been taken in order to stem the damage caused by the new competition. 36 of the 37 respondents identified discount retail chains as their competitors, with Costco and Home Depot cited by 20 of them; also cited as discount-chain competitors were WalMart, and the fumiture, appliances and electronics chains Future Shop, The Brick, and Leon's. This group of respondents includes both stores selling general merchandise at a discount and specialized stores selling furniture, electronics and other specialized merchandise. 
The decline in clientele traffic was also more pronounced among unsuccessful retailers, as compared to the general respondent population: minus $18.24 \%$ for clients from Sudbury, and minus $9.2 \%$ for out-of-region customers. The categories of businesses who saw declining sales mostly include hardware, paint, and wallpaper stores, food stores, discount stores, stationery and book stores and general merchandise stores. These categories of stores were affected regardless of their urban, suburban or more rural location, as t-tests comparing means across locations showed no significant difference for the variables above. Businesses with lower sales volumes did not significantly differ in terms of their years of existence of 23 years.

\section{Resisting Retailers}

Another 33 respondents ( 8 declined to answer the question about their sales volumes), or $42.3 \%$, reported stable sales in 17 cases, and average increases of $21.6 \%$ in 16 cases, for an overall increase in sales average of $10.5 \%$ over the years following the arrival of the major box-retailers. These figures are consistent (even if substantially higher) with those reported by Stone (1995) for specialty stores' sales in cities with a Wal-Mart store in rural Iowa after five years, of $+5.5 \%$. The higher figure observed in Sudbury is likely related to the size of the market area described above, as compared to rural Iowa.

Profitability was reported as being up by $7.3 \%$ by these 33 retailers, and up by $20 \%$ on average by the 16 respondents who had net sales increases. In contrast with their unsuccessful counterparts, resisting retailers increased both their full- and part-time personnel since the mega-stores arrival, respectively from 3.67 to 4.33 on average for fulltime employees, and from 2.82 to 3.42 for part-time employees. The absolute numbers of full- and part-time employees were not significantly different between resisting retailers and the overall respondent population. Similarly, store sizes were not significantly different from the overall average of 3,220 sq. $\mathrm{ft}$.

In the case of resisting retailers, customer traffic from outside Greater Sudbury had increased by $11 \%$ since the mega-retailers' arrival, while local traffic had increased by $6.4 \%$. These retailers cited most often $(60.6 \%)$ local stores as their competitors, and were of the opinion that mega-retailers offered "low-end, inexpensive products" they were not interested in competing against. Only $18 \%$ of them cited Home Depot, Wal-Mart, Leon's, Rona Cashway, Sears, and Home Sense, as their primary competition. Meanwhile, Costco was only cited by five respondents, as a second main competitor (one case), or as a third main competitor (four cases).

The categories of businesses represented among the 33 resisting retailers include specialty shops such as opticians, prescription drug stores, shoe, apparel and fabric stores (including higher end men's and women's clothing stores and specialty shops), household furnishing, electronics and appliance stores, book and stationery stores (with an established institutional and corporate clientele), florist shops, lawn and garden centers, sporting goods stores, musical instrument and record stores, jewelry stores, camera and photographic supply stores, toy, gift, hobby and novelty stores, artists' supplies stores, luggage stores, pet shops, and discount retailers. Only two hardware, paint and wallpaper stores appeared in this group of resisting retailers. Four small general-merchandise retailers (corner stores) appeared in this group, and one discount store. Again, location in one area of the city or another had no incidence on being part of this group (which invalidates hypotheses 6 and 7), and, with an average of 21.6 years in operation, these retailers were no different in terms of business longevity from their unsuccessful peers. 


\section{Strategic Variables}

The scale results comparing the smaller store owners' perceptions of their retail strategy as compared to the mega-box retailers' strategic variables are summarized in Table 1. Ttests comparing the perceptions of resisting entrepreneurs to unsuccessful ones showed no significant differences between the two groups on mean strategic variables scores, except for one (see below). While the scores are self-reported by the respondents, they show a strong awareness from their part of their respective position of strength or weakness as compared to mega-retailers on the 18 variables, thus confirming hypotheses 3 and 4 .

Table 1. Competitiveness Scales Data: Small Retail Store Owners' Self-ratings as Compared to Their Ratings of Mega-stores

\begin{tabular}{|c|l|c|c|c|}
\hline Berry's Pillars & \multicolumn{1}{|c|}{ Variable } & Mean small & Mean mega & t-test significance \\
\hline P1 & Competence of salespeople & 81.47 & 34.93 & .000 \\
\hline P1 & Availability of salespeople & 76.19 & 36.59 & .000 \\
\hline P1 & Service quality & 88.41 & 34.64 & .000 \\
\hline P2 & Respect for customers & 91.76 & 41.32 & .000 \\
\hline P2 & Courteous salespeople & 89.85 & 40.75 & .000 \\
\hline P3 & Store cleanliness & 80.90 & 50.15 & .000 \\
\hline P3 & Choice/variety of products & 73.38 & 66.76 & .257 n.s. \\
\hline P3 & Suppliers/supply chain & 69.77 & 59.22 & .072 n.s. \\
\hline P3 & Value for customer & 73.79 & 53.1 & .000 \\
\hline P3 & Products' quality & 82.00 & 55.46 & .000 \\
\hline P4 & Fair prices & 78.28 & 59.92 & .000 \\
\hline P4 & Avoidance of hidden charges & 79.84 & 50.16 & .000 \\
\hline P5 & Store location & 61.94 & 67.42 & .339 n.s. \\
\hline P5 & Easy access & 71.31 & 69.67 & .738 n.s. \\
\hline P5 & Easy parking & 70.97 & 67.74 & .573 n.s. \\
\hline P5 & Shopping hours & 70.00 & 70.97 & .823 n.s. \\
\hline P5 & Store layout & 81.31 & 62.46 & .000 \\
\hline NOTE: Each scale was from 0 to 100. The t-tests were paired-samples tests. & \\
\hline II terms & re respondent perceptions & \\
\hline
\end{tabular}

In terms of the respondents' perceptions of using most of Berry's best retailing practices, the Solving Customers' Problems (P1), Respect for Customers (P2), and Fair Pricing (P4) subscales were the areas where they felt had a strategic marketing advantage against mega-store competitors. On the Connecting with Customer Emotions Through Retail Experience (P3), and Saving Customers' Time (P5) subscales, respondents had a significant perception of having an advantage over their mega-competitors in the areas of Store Cleanliness (i.e. smaller stores being cleaner than the larger ones), Value for the Customer, Products' Quality, and Store Layout (i.e. smaller stores being non-confusing in their layout relative to mega-stores).

On the latter two subscales, the respondents did not see themselves significantly different from the mega-retailers on the six following strategic variables:

1. Choice and Variety of Products;

2. Suppliers/supply chain;

3. Store location;

4. Convenient shopping hours (however, there was a significant difference at $p<0.005$ 
level between unsuccessful and resisting retailers' mean scores ( 58.6 vs. 77.1$)$ for this variable, perceived as less important by the resisting group);

5 . Easy access by road;

6. Easy parking.

\section{Planning Innovative Competitive Strategies against Mega-retailers}

The fifth hypothesis was more qualitative in proposing that smaller retailers were involved in planning marketing strategies that would allow them to compete effectively against the mega-retail competition. Three qualitative questions were used to verify this hypothesis: What strategies, if any, have you taken to compete against other retailers? How can you compete with the large discount retail chains? Have you considered: a) Associating with other retailers in your area in order to compete against box retailers? b) Starting a joint venture with other retailers in your area in order to compete against box retailers? c) Associating with a box retailer who is not in direct competition, but rather complementary to your business?

Most of the retailers identified as resisting the mega-stores, as well as a few unsuccessful ones, did not respond directly to the last questions above, but described specific strategies they were using to compete as successfully as possible. Below are a number of them, but first these two statements made by resisting respondents provide some background on their state of mind towards mega-retailers.

Statement 1. Many of the box retailers that have come to Sudbury have not affected our business in a typical sense. We are a small mid-to-high-end furniture store and therefore the product in many box stores does not compete with our business. However, I do feel they have had a very negative effect on business because of the mentality of the consumer as a result of box stores. The small business has been forced to advertise on a constant basis with the word "Sale." It means we are forced to spend more money on advertising and in truth the product is probably on sale every day of the week. I have seen box and mattresses advertised at chain stores at $\$ 2,200$ for half price $(\$ 1,100)$, when the exact same product is in our store every day at $\$ 995$. This is a result of the consumer just needing to see the word "Sale," what I refer to as the box-store mentality. I only hope that the consumer becomes smarter when reading advertising of box stores.

Statement 2. Sudbury's non-growth and the loss of small competitors have helped the strong survive. Sudbury is the Toronto of the North, which brings in people for the weekend from out of town, for the theatre, hospitals, schools, Science North and box stores. In return, hopefully the money spent at restaurants, gas stations, accommodations will gradually sift through the system and get to the small retailer. The small retailer has to find their niche to survive. Toronto is our biggest competitor.

\section{Brand and Product/Service Strategies}

To improve their financial situation, resisting retailers had dropped lines of products and/or brands sold by big box stores to replace them with others, sometimes more exclusive and expensive, or likely to deliver higher margins and sell faster. Others reduced costs and increased prices on more exclusive products or decided to stop discounting major products, limiting sales and quantity deals to accessories (such as belts and jewelry), thus securing a more exclusive store image and a better connection with high-income customers' self-image.

Solving customers' problems meant emphasizing a specific service, important to one 
or more significant segments of clientele, such as enhanced delivery services. For example, a building supply store offers on-roof shingle delivery, a service not offered by the competing mega-retailer and worth more in time and wages to roofing contractors than the extra cost to them. It also meant offering better repair services, faster, done on a local basis and for longer periods. A local computer store offers three-year warranties on several products, thus securing a loyal clientele.

Other retailers reported giving customers more discretion in their choice of a specific product. Smaller lumber retailers allowed their customers (building contractors) to choose each individual plank, while mega-retail stores oblige their clients to take delivery of whatever planks handled by their sales personnel, regardless of knots or imperfections. Hardware store owners reported having a competent and better-paid sales force to retain customers and secure repeat business as well as word-of-mouth publicity from loyal customers: competent and well-experienced personnel will provide clients with invaluable advice on how to replace obsolete plumbing with proper-fitting supplies, saving clients the frustration of having to submit to multiple visits to the store in order to find the proper replacement product.

In terms of products offered, some retailers increased their store size in order to expand product lines which are not fully available at mega-stores: in given product categories, mega-stores often carry only one or two items (for example musical instruments, compressors, seasonal clothing, vacuum cleaners, ladders, office and home furniture). Other retailers said they advised customers they would refuse to service or repair brands sold exclusively by mega-retailers.

\section{Promotional and Communication Strategies}

One store owner said it would be important to educate customers and make them realize what Big Box stores foster: a low-wage, low-cost economy with no job security, which is the opposite to what local consumers keep asking for from their large local employers (branches of large national banks, mining and paper companies, other local branches of large multinational and global corporations, governments, hospitals, schools and publicsector employers): higher wages and job security.

Some of the food stores, which are affiliated with larger national wholesale chains, had developed promotional material attacking Costco directly, with point-of-purchase slogans suggesting to customers they could pay similar prices and get a better deal: "No Membership Required"; "Buy Large Packs and SAVE"; "Count on us for More." At the same time, these same stores paid attention to limit waiting at cash outlets and to customer satisfaction by asking, for example, whether customers found all the products they were looking for that day and providing them with some form of meaningful answer in case they did not. Such practices are consistent with recent research findings on improving customers' retail experience (Berry, Carbone and Haeckel, 2002; Walash, 2003; Rosenblum, 2004), particularly with respect to the fact that many consumers are ready to sacrifice money for time saved up to a certain limit.

\section{Supply Chain Strategies}

Regarding supply channels, some retailers developed or joined contractual channels such as purchasing retail groups, wholesale chains and national franchises. Others were seeking the engagement from as many manufacturers as possible to guarantee that products supplied to mega-retail stores would be different from those sold to smaller retailers in terms of quality and product attributes. 
By their mere presence, mega-retailers significantly disrupted the supply chain of several categories of retailers. This appeared particularly important in the hardware and food products categories. Consider cordless power tools such as saws, routers, drills, and other small hand tools: in the pre-mega-retail era, hardware store owners would buy them from a contractual national supplier at a price of, let us assume, $\$ 59.99$, and sell them at retail for $\$ 79.99$. The same tools are available now at a local mega-store for $\$ 39.99$ each, thus undercutting both the retail and wholesale former prices. Smaller retailers were left with limited choices, including dropping the whole product line (not a viable choice for a hardware store on such a staple product line), dropping the brand in question and seeking another competitive one, or convincing the national supplier to create a new product line under an existing national private brand or under a new brand name altogether (with all the development and promotion costs associated with such a move).

\section{General Strategies: The Vacuum Strategy}

In general, differentiation and niche marketing were the main aspects of a successful competing strategy adopted by smaller retailers against mega-retailers. Some of the strategic moves adopted by resisting retailers amount to what can be called a "Vacuum Strategy," the components of which include:

1) The refusal to carry as many brands as possible that are carried by mega-stores;

2) The refusal to service such brands, and

3) The refusal to have anything to do with mega-retailers, any kind of alliance or cooperation with them.

These moves were clearly not concerted from the part of the smaller retail entrepreneurs, but those who defended and advocated these moves made it clear that it was also important for them and part of their strategy to inform their customers of these actions. These retailers were deliberately turning their backs on mega-retailers in an attempt to isolate them from the local customer base on as many product lines as possible. Better sales and profits would be secured through appropriate branding, pricing, customer experience, and product/service differentiation among their specialty product categories.

While it is too early to say whether such strategies will keep a significant core of successful smaller retailers in the Greater Sudbury area, it is important to understand that retail wars do not occur in a vacuum, but within a larger economic and social-political context in constant evolution. That context is not only influenced by private industry competition, but also by decisions taken by the various levels of government. Meanwhile, the overall economy of the region has been affected by international demand, particularly for metals, which are the main exportable by-product of the local economy besides agricultural products such as beef, deer, buffalo, meat, and cereals. These issues are the subject of the following discussion on mediating factors.

\section{Mediating Factors}

The economy of the CGS and Northern Ontario has been described as involving two groups of major employers, large corporations on one side, and local, provincial, and federal governments on the other (Cachon et al., 2001), both groups providing average incomes more than twice those obtained within firms of less than twenty employees (Mulholland et al., 1998: 26). The relative importance of small business and entrepreneurship in the economy of the region has yet to be determined, but it is almost certain that both large corporations and governments, who provide a strong employment base to the area, play a major role in sustaining local small businesses, particularly within the 
retail sector. Retail sales involve store sales to the general public as well as procurement contracts for institutions and corporations.

The local economy of the CGS suffered setbacks between 1996 and 2001: Statistics Canada data issued following the 2001 Census showed a decline in the Greater Sudbury area population of about 10,000 people during that period. It is likely that a large proportion of the population decline resulted from the loss of employment in three key levels of government which all implemented personnel-reduction programs during the period 1996-2001. Meanwhile, there are indications that, in the private sector, areas such as the mining services industry gained jobs and were still expanding through 2004 and 2005 due to the high level of metal prices (a total of twelve metals are mined in Sudbury, which is still considered the largest nickel-cobalt-copper ore basin in the world: nickel, cobalt, copper, gold, silver, the six platinum group metals, and iron).

It is certainly likely that these two phenomena had an impact on retail sales in the region, in addition to the arrival of mega-retailers. It is also possible that the long-term effects of the mega-retailers' presence in the Greater Sudbury area will take more than a few years to show themselves clearly, at least on some sectors: Stone (1995) has shown that mega-retailers continued to have a negative impact on Iowa rural communities' restaurants after five years of presence.

\section{Conclusion and Other Considerations}

The overall results showing declining sales, particularly among general merchandise and hardware stores, are consistent with findings from other empirical research (Doucet and Jones, 1999; Stone, 1995 and 1997). Secondary data showing an increase in sales per capita in Sudbury are also consistent with the literature. However, while the effects of location were hypothesized to be a significant success factor, this proved to be not the case in this study. This might be explained by the relative ease of access to all areas of the Sudbury Basin for customers.

Smaller retailers were well aware of their competitive position and, at least some of them, believed they were adopting adequate strategic marketing responses to their new competition. At the same time, many of the respondents were not properly informed of the role played by local and other levels of government respective to the mega-retail entry into the CGS market. A number of them were convinced that mega-retailers had been receiving tax incentives and various types of "tax breaks" for which local small owners were not being compensated; they were also questioning the local support provided by mega-retailers in terms of charities, sponsorships, giveaways and other demonstrations of good corporate citizenship. There seemed to be a deficit of information between some of the small retailers and the various levels of government about what is being done to sustain and promote local business while keeping a healthy level of competition within the retail sector in the region and the country. It can certainly be assumed that similar ignorance is present among a majority of customers and the general public.

Resisting, or successful retailers were concentrated mostly in the specialty shopping categories, including corner stores with vast assortments of products available at hours where the mega-stores are closed and located in residential neighborhoods. Unsuccessful retailers were more likely to be confronted by mega-retailers on identical product lines and brands, or on products perceived by customers as being homogeneous in nature rather than differentiated.

With regards to locating the retail business, the relatively small size of the city, coupled with the ease with which customers can drive from one shopping zone to another, 
rendered the fact of being located nearer or farther apart from the mega-retailers not significant in being successful as a resisting retailer. It is more likely that successful advertising in the local media would ensure customer visits from both local and out-of-town people, as long as the proper market strategies are also put into practice.

It is likely that mega-retailers also affect the supply chain for many smaller retailers in the northeastern Ontario and northwestern Quebec areas, including those located in smaller towns and in rural areas. As in one of the aforementioned examples, some respondents have indicated that some prices obtained at Costco and Home Depot are lower than their wholesale prices: this prompted some of them to switch from a former wholesaler to mega-retailers as their primary supplier. However, these strategic moves are not necessarily available to all retailers, many of them being members of exclusive distribution channels such as franchises, which prevent them from seeking alternate supply sources.

\section{Other issues}

There are other issues related to the development of mega-retail power centers which were not within the scope of this research but are nonetheless important. They particularly revolve around community planning, social, and environmental issues. Studies and reports such as Beaumont (1994), Duerksen and Goebel (1999), and Perry (2001) provide examples and guidelines on how community leaders and planners should establish relevant legislation and control mechanisms in order to limit the potentially negative effects of megaretail. Perry reports a series of regulatory strategies adopted across the United States, including Mequon (Wisconsin), St. Petersburg (Florida), Fort Collins (Colorado), and the states of Vermont and New Jersey; the report provides specific recommendations for public authorities at the local and regional (state) level to coordinate and engage in reviewing the impacts and planning retail development.

There is a need for another study of the customers' perspective on these aspects, as it can be argued that, in the final analysis, it is customers who decide which retailers will be successful.

\section{Contact Information}

For further information on this article, contact

J.-Ch. Cachon, School of Commerce and Administration, Laurentian University, 935 Ramsey Lake Road, Sudbury, Ontario, Canada P3E 2C6

Telephone: (705) 675-1151, ext. 2126/Fax: (705) 673-6518

e-mail: jccachon@laurentian.ca

\section{References}

Archer, J.S. and D. Taylor. 1994. Up Against the Wal-Marts. New York: American Management Associations. Beaumont, C.E. 1994. How Superstore Sprawl Can Harm Communities... And What Citizens Can Do About It. Washington: National Trust For Historic Preservation.

Berry, L.L. 1999. Discovering the Soul of Service. New York: Free Press.

2001. "The Old Pillars of New Retailing," Harvard Business Review 79, no. 4: 131-37.

Berry, L.L., L.P. Carbone and S.H. Haeckel. 2002. "Managing the Total Customer Experience," Sloan Management Review 43, no. 3: 84-89.

Cachon, J.-C. 1990. « Perception du rôle d'une caisse populaire » Revue du Nouvel-Ontario 12: 205-15.

Cachon, J.-C. et al. 2001. "Les entrepreneurs Franco-Ontariens dans les PME du Nord de l'Ontario : contexte économique, profil général et profil sectoriel," Revue du Nouvel Ontario 26: 9-44.

Cachon, J.-C. and G.B. Cotton. 1997. The IN.O.V.E. Project. Sudbury, ON: Laurentian University.

Chirouze, Yves. 2003. Le Marketing : Études et Stratégies. Paris : Ellipses Éditions Marketing. 
Dalal, M., J. Al-Khatib, M.N. DaCosta and R. Decker. 1994. "Why do Small Towns Lose Retail Business? An Empirical Investigation," Mid-Atlantic Journal of Business: 241.

Doucet, M.J. and K.G. Jones. 1999. The Impact of Big-Box Development in Toronto and Retail Structure. Toronto: Centre for the Study of Commercial Activity, Ryerson University.

Duerksen, C. and R.M. Goebel. 1999. Aesthetics, Community Character and the Law. American Planning Association: Planning Advisory Service.

Evans, W., K.G Jones, R. Gomez-Insausti and D. Kendal. 2003. European Retailers in the North-American Market: the Next Wave for Canada? Toronto: Centre for the Study of Commercial Activity, Ryerson University.

Fruth, W.H. 2000. The Flow of Money and Its Impact on Local Economy. National Association of Industrial and Office Properties.

Gonzalez-Benito, O. 2001. "Inter-Format Spatial Competition of Spanish Hypermarkets," International Review of Retail, Distribution and Consumer Research 11, no. 1: 63-81.

Hernandez, T., M. Biasiotto and K.G. Jones. 2003. Power Retail: Growth in Canada and the GTA.Toronto: Centre for the Study of Commercial Activity, Ryerson University.

Hernandez, T., K.G Jones and A. Maze. 2003. U.S. Retail Chains in Canada. Toronto: Centre for the Study of Commercial Activity, Ryerson University.

Jones, K.G. and M.J. Doucet. 1998. The Big Box, the Big Screen, the Flagship and Beyond: Impacts and Trends in the Greater Toronto Area. Toronto: Centre for the Study of Commercial Activity, Ryerson University.

Lea, T., K.G. Jones and G. Bylov. 2003, Retail Sales Trends in Downtown Canada. Toronto: Centre for the Study of Commercial Activity, Ryerson University

Malone, Given, Parsons. 1996. Preliminary Market Review and Impact Evaluation for a Warehouse Membership Club: The Kingsway.

Marks, R.B. 1976. “Operationalizing the Concept of Store Image," Journal of Retailing 52: 37-45.

Mulholland, R., H. Blanco, J.-C. Cachon, C. Vincent and T. Zinger. 1998. The State of Small Business and Entrepreneurship in Northern Ontario. Industry Canada-FedNor.

Perry, T.L., Jr. 2001. Managing Maryland's Growth: "Big Box" Retail Development. Baltimore, MD: Maryland Department of Planning.

Rosenblum, P. 2004 "In-Store Tactics Drive Value," Chain Store Age 80, no. 11: 56

Shils, E.B. and G.W. Taylor. 1997. Measuring the Economic and Sociological Impact of the Mega-Retail Discount Chains on Small Enterprise in Urban, Suburban and Rural Communities. Philadelphia: University of Pennsylvanja, Wharton School, Wharton Entrepreneurial Center.

Simmons. 2003. Cities in Decline:the Future of Urban Canada. Report no. RL 2003-07. Toronto: Centre for the Study of Commercial Activity, Ryerson University. http:/www.csca ryerson.ca/Publications/2003-07 htm Stone, K.E. 1995. Competing with Discount Mass Merchandisers. Ames, IA: Iowa State University of Science and Technology

1997. Impact of the Wal-Mart Phenomenon on Rural Communities. Ames, IA: lowa State University of Science and Technology.

Stone, K.E. and GM. Artz. 1999. Iowa Retail Market Share of Various Size Towns. Ames, IA: Iowa State University of Science and Technology.

Walash, F. 2003. "How America Shops: A Special Research Report," Sporting Goods Business 36, no. 11:20-33. 